\title{
Learning Style Preferences of Undergraduate Medical Students: A VARK Profile
}

\author{
Dr. Asha Rani N*
}

Associate Professor, Department of Biochemistry, Adichunchanagiri Institute of Medical Sciences, B G Nagara Adichunchanagiri University Karnataka India

DOI: $10.36348 /$ SIJB.2019.v02i10.003

| Received: 18.10.2019 | Accepted: 25.10.2019| Published: 30.10.2019

*Corresponding author: Dr. Asha Rani N

\section{Abstract}

Every student has different learning style and if the method of information delivered conforms to their learning habits, they learn better. To get best out of a student, facilitator needs to understand the student's learning modalities and 'tailor instruction' in such a way that students appreciate and follow it to learning. In this regard a study was designed to analyze the learning style distribution among 1st year MBBS students. A cross sectional questionnaire based study was conducted among $1^{\text {st }}$ year MBBS students $(n=152)$ using validated VARK questionnaire (version 7.8). The questionnaire consists of 16 questions with 4 options, each of which corresponds to a particular sensory modality preference (visual, aural, $\mathrm{read} /$ write and kinesthetic). The responses in the questionnaires were assessed according to the keys provided in VARK guide. Demographic details were collected. Preferred learning styles were expressed as frequency and percentage. The response rate was $86.18 \%$ (131 students out of 152$)$. Of these $71(54.2 \%)$ were female and $60(48.8 \%)$ were males. All the students preferred more than one sensory modality with $98 \%$ quad modal $(\mathrm{n}=129, \mathrm{M} / \mathrm{F}=59 / 70)$ and near $1 \%$ each in tri modal $(n=1, M / F=1 / 0)$ and bimodal $(n=1, M / F=0 / 1)$ learning preference. Knowing student's preferred learning modes; one can focus on developing strategies that are tailored for individuals. All the students in the present study showed multimodal learning styles which points towards the fact that they prefer information to arrive in a variety of modes. Lectures being the major proportion of teaching learning process in $1^{\text {st }}$ MBBS curriculum, one need to adopt active learning strategies and process during lectures which will cater to the needs of all types of learners.

Keywords: Learning style, learning preference, Medical students, VARK questionnaire.

Copyright @ 2019: This is an open-access article distributed under the terms of the Creative Commons Attribution license which permits unrestricted use, distribution, and reproduction in any medium for non-commercial use (NonCommercial, or CC-BY-NC) provided the original author and source are credited.

\section{INTRODUCTION}

Teaching and learning is a two-way process, both teacher and learner needs to update themselves continuously. The ways in which an individual normally acquires, retains, and retrieves information are defined as the individual's learning style. There is always a challenge while imparting a substantial amount of knowledge within a limited time period in a way it is retained, recalled and effectively interpreted by a student. Because preferred modes of input and output vary from one individual to another and it is critical that the facilitator use a mixed bag of teaching strategies to effectively meet the needs of individual learners. Every student has different learning habits, if the method of information delivery conforms to their learning habits; they learn better [1]. To get best out of a student, facilitator needs to understand the student's learning modalities and 'tailor instruction' in such a way that students appreciate and follow it to learning [2]. In this regard the present study was designed with an objective to assess the preferred learning styles among $1^{\text {st }}$ year MBBS students.

"The effectiveness of professional development depends on how carefully educators conceive, plan and implement it"- Hayes Mizell, Why Professional Development Matters. Learning Forward, 2010.

\section{MATERIAL AND METHODS}

A cross sectional questionnaire based study was conducted among $1^{\text {st }}$ year MBBS students of Adichunchanagiri Institute of Medical Sciences. A well tested, validated and globally accepted VARK questionnaire (Version 7.8) [3,4] was used as a tool to assess the preferred learning styles of the students. The questionnaire consists of 16 questions with 4 options, each of which corresponds to a particular sensory modality preference (visual, aural, read/write and kinesthetic). 
The study population included all $1^{\text {st }}$ year MBBS students $(n=152)$. After obtaining ethical clearance from institutional ethical committee, all the participants were briefed about the research proposal. Participants not willing to participate $(n=14)$ and absent on the day of data collection $(n=07)$ were excluded from the study. Finally, 131 students filled and submitted the google form of VARK questionnaire. The submitted questionnaires were assessed according to the keys provided in VARK guide [5]. The responses entered in excel sheet was managed in SPSS. Preferred learning styles were expressed as percentage for each category.

\section{RESULTS AND DISCUSSION}

A total of $152,1^{\text {st }}$ year MBBS students were invited to participate in the study and finally 131 students consented to provide demographic details and answer the VARK questionnaire. The response rate was $86.18 \%$. Of these $71(54 \%)$ were female students and $60(46 \%)$ were males. The mean age of study participants was $19.72 \pm 1.32$ years. Almost all students preferred more than one sensory modality for learning with $98 \%(n=129)$ in quad modal and approximately $1 \%$ each in tri modal $(n=1)$ and bimodal learning style $(\mathrm{n}=1)$.

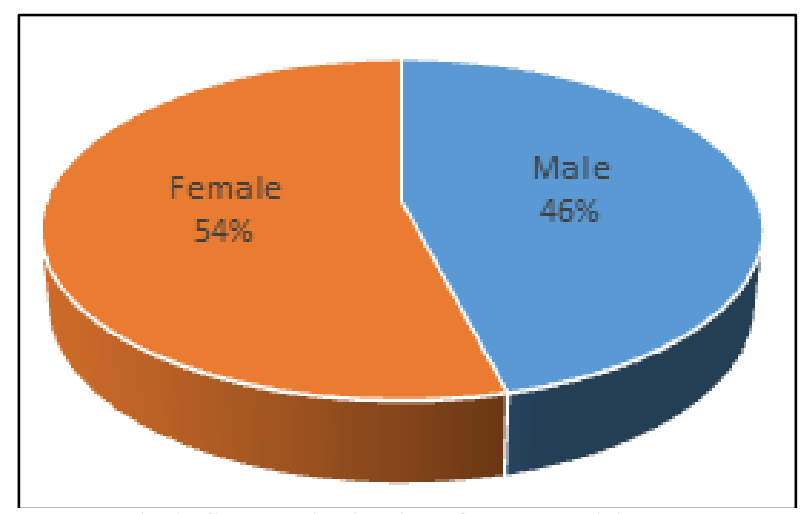

Fig-1: Gender distribution of study participants

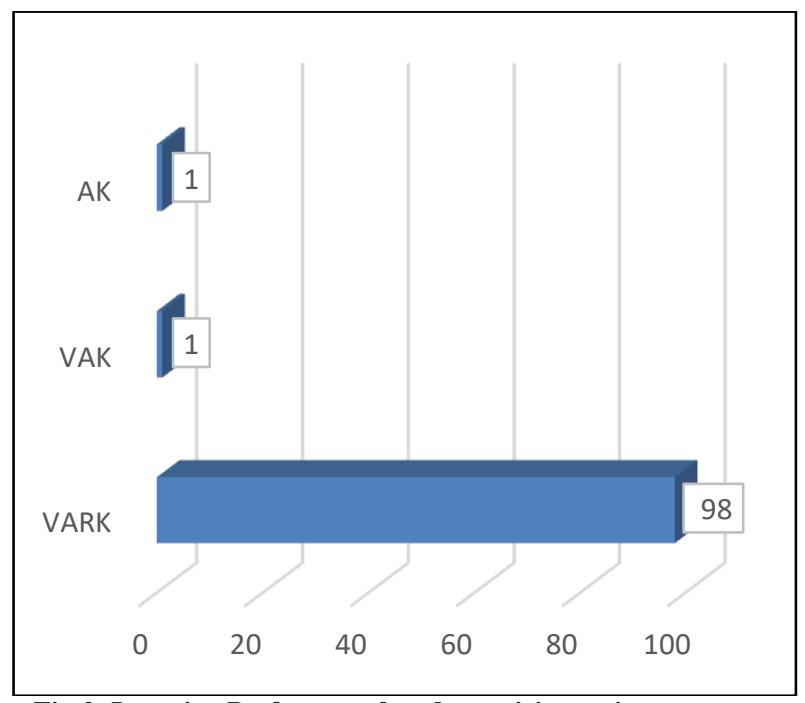

Fig-2: Learning Preference of study participants in percentage
In this study, a VARK questionnaire (version 7.8) was administered to first-year medical students to determine their preferred modes of information presentation.

Keefe defined a learning style as 'the composite of cognitive, affective and psychological characteristics that serves as relatively stable indicator of how a learner perceives, interact and responds to a learning environment'[6].

Assessment of students' learning style is a valuable skill in education. Knowledge of learning styles may help educators identify and solve learning problems among students, thus helping their students to become more effective learners [7]. A variety of factors can influence students learning approaches. The challenge of imparting a large amount of knowledge within a limited time period in a way it is clearly understood and retained by a student is a formidable one [8].

The present study showed that majority of the medical students preferred to learn using all VARK modalities. As the students of present study have significantly different learning styles; it is the responsibility of the instructor to address this diversity of learning styles among the students and develop appropriate learning approaches [9]. Similar results have been reported by few researchers $[10,11]$. Further, knowing the learning preferences of students is a precious skill and technique in teaching. It will aid the facilitator to identify and work out learning troubles among students, thus helping the students to become more effective and successful learners.

It has been argued that knowledge of learning styles can be useful to both teachers and students, in that teachers can tailor pedagogy to correlate with the learning styles of students $[12,13]$. Similarly, students with knowledge of their learning styles could be empowered to identify and use the techniques of learning best suited to their individual styles, resulting in greater educational satisfaction.

Most students are able to learn effectively as long as the teacher provides a blend of visual, auditory, reading/writing, and kinaesthetic activities. However, some students prefer one of the modalities over the other three so strongly that they struggle to understand the subject matter unless special care is taken to present it in their preference mode. To meet these needs, teaching should be multisensory, filled with variety and use active learning strategies [14].

The active learning strategies may be superior to the traditional lecture format in promoting thinking, reasoning, problem solving and decision making skills. Inclusion of the active learning strategies like 
cooperative learning exercise, role playing, simulations, models, debates and games in the lectures may make the learning of concepts in medical education an effective one.

These activities also promote working in groups and generate high levels of motivation and enthusiasm. This is important because employment opportunities in the future will require employees to work cooperatively to solve problems and develop solutions. For all these reasons, active learning strategies may be superior to the traditional lecture format in promoting thinking, reasoning, problemsolving, and decision-making skills.

\section{CONCLUSION}

In conclusion, the present study was an attempt to determine the learning styles of undergraduate medical students in our institution. Majority of the students were multimodal learners. Instructors should be sensitive to the students learning preferences. Knowledge of students learning styles can give the instructor some insight into the characteristics of the student. Lectures being the major proportion of teaching learning process in $1^{\text {st }}$ MBBS curriculum, one need to adopt active learning strategies / process during lectures which will cater to the needs of all types of learners.

\section{ACKNOWLEDGEMENT} the study.

We thank all the students who participated in

\section{REFERENCE}

1. Sadler-Smith, E, Smith, P. J. (2004). Strategies for accommodating individuals' styles and preferences in flexible learning programs. Br J Educ Technol. 35:395-412.

2. Collins, J. (2004). Education techniques for lifelong learning: Principles of adult learning. Radiographics, 24:1483-9.

3. Fleming, N.D., Mills, C.(1992). Not another inventory,rather a catalyst for reflection. Acad Med.11:137-44.

4. Leite, W.1., Svinicki, M., Shi, Y. (2010). Attempted validation of the scores of the VARK: learning styles inventory with multitrait- multimethod confirmatory factor analysis models. EducPsychol Meas.70:323-39.

5. Fleming, N.D. (2015). VARK: Aguide to Learning Styles. Available from:http://www.vark-learn.com (Last accessed on Jan 2018).

6. Keefe, J.W, editors. Learning style. (1987). Theory and Practice. Reston (USA): National Association of Seconadry School Principal.

7. Sadler-Smith, E., \& J. Smith, P. (2004). Strategies for accommodating individuals' styles and preferences in flexible learning programmes. British journal of educational technology, 35(4), 395-412.

8. Samarakoon, L., Fernando, T., Rodrigo, C., \& Rajapakse, S. (2013). Learning styles and approaches to learning among medical undergraduates and postgraduates. BMC medical education, 13(1), 42.

9. Tanner, K., \& Allen, D. (2004). Approaches to biology teaching and learning: learning styles and the problem of instructional selection-engaging all students in science courses. Cell biology education, 3(4), 197-201.

10. Urval, R. P., Kamath, A., Ullal, S., Shenoy, A. K., Shenoy, N., \& Udupa, L. A. (2014). Assessment of learning styles of undergraduate medical students using the VARK questionnaire and the influence of sex and academic performance. Advances in physiology education, 38(3), 216-220.

11. Anu, S., Anuradha, Meena, T. (2001). Assessment of learning style preferences among undergraduate medical students using VARK assessment tool. International Journal of Medical and Clinical Research. 3(8)

12. Newble, D.I., Entwistle, N.J. (1986). Learning styles and approaches: implications for medical education. Med Educ. 20(3):162-75.

13. Lubawy, W.C. (2003). Evaluating teaching using the best practices model. Is $\mathrm{J}$ Pharm Educ. 67(3):87?

14. Rao, S.P., \& DiCarlo, S.E. (2001). Active learning of respiratory physiology improves performance on respiratory physiology examinations. Adv Physiol Educ.25: 55-61. 